University of Nebraska - Lincoln

DigitalCommons@University of Nebraska - Lincoln

Nebraska Cooperative Fish \& Wildlife Research Nebraska Cooperative Fish \& Wildlife Research Unit -- Staff Publications

1996

\title{
Seasonal Influences on Freshwater Fisheries Sampling Data
}

Kevin L. Pope

South Dakota State University, kpope2@unl.edu

David W. Willis

South Dakota State University

Follow this and additional works at: https://digitalcommons.unl.edu/ncfwrustaff

Part of the Other Environmental Sciences Commons

Pope, Kevin L. and Willis, David W., "Seasonal Influences on Freshwater Fisheries Sampling Data" (1996). Nebraska Cooperative Fish \& Wildlife Research Unit -- Staff Publications. 64.

https://digitalcommons.unl.edu/ncfwrustaff/64

This Article is brought to you for free and open access by the Nebraska Cooperative Fish \& Wildlife Research Unit at DigitalCommons@University of Nebraska - Lincoln. It has been accepted for inclusion in Nebraska Cooperative Fish \& Wildlife Research Unit -- Staff Publications by an authorized administrator of DigitalCommons@University of Nebraska - Lincoln. 
Reviews in Fisheries Science, 4(1): 57-73 (1996)

\title{
Seasonal Influences on Freshwater Fisheries Sampling Data
}

\author{
Kevin L. Pope and David W. Willis \\ Department of Wildlife and Fisheries Sciences, South Dakota State University, Brookings, \\ SD 57007
}

\begin{abstract}
Fisheries managers often assess fish populations using catch per unit effort (CPUE), size and age structure, growth, and condition. For many freshwater fishes and common sampling gears, CPUE, size and age structure, and condition are highest in the spring and fall, while growth commonly is fastest during the summer growing season. However, there are exceptions to these general trends, especially in populations with erratic recruitment, growth, or mortality. At the least, CPUE, size and age structure, growth, and condition of fish should be expected to change with season, given the effects of variable recruitment, growth, and mortality. However, if recruitment, growth, and mortality are relatively stable, seasonal changes in sampling data occur due to changes in fish behavior caused by many factors (e.g., changes in temperature, turbidity, food availability, photoperiod, etc.). However, these patterns of change through the seasons should not necessarily be assumed to be the same for all fish species or for species in all habitats or geographic regions. Thus, managers and researchers need to consider the seasonal patterns in sampling data for a particular species within a certain habitat in their geographic region when collecting standardized data sets, and when assessing populations and communities.
\end{abstract}

KEY WORDS: catch per unit effort, size structure, age structure, growth, condition

\section{INTRODUCTION}

Fisheries managers often assess fish populations using catch per unit effort (CPUE), size and age structure, growth, and condition. However, these parameters are often influenced by the season in which data are obtained.

For example, assume that a biologist is asked to sample largemouth bass (Micropterus salmoides) for the first time (no previous sampling has occurred) in a Midwestern impoundment. The only possible time to obtain the sample occurs in July during the day because of time limitations. This sample likely will include few largemouth bass that exceed $30 \mathrm{~cm}$. If this sample size structure is accepted at face value, the biologist may conclude that the population is either overharvested or overpopulated. However, night electrofishing in spring or fall when the water temperature is near 18 to $20^{\circ} \mathrm{C}$ likely would have resulted in a substantially greater proportion of large (e.g., $\geq 30 \mathrm{~cm}$ ) largemouth bass in the sample. Proper assessment of a population requires an understanding of seasonal sampling biases along with an understanding of gear sampling biases. 
Thus, it is important to understand how sample characteristics change among months so that proper inferences can be drawn based on the sampling data collected. The purposes of this paper are to review (1) seasonal variation in CPUE, size and age structure, growth, and condition, and (2) interactions between gear biases and seasonal biases as they affect sampling data.

\section{WHY DO SEASONAL CHANGES OCCUR?}

Seasonal changes in sampling data are due to changes in fish behavior and physiology, and are influenced by many factors (e.g., changes in temperature, dissolved oxygen, turbidity, food supplies, photoperiod, etc.). These seasonal changes are easily seen in steady-state populations (i.e., populations with relatively stable or consistent recruitment, growth, and mortality). For example, Mero and Willis (1992) documented seasonal variation in CPUE and size structure for walleyes (Stizostedion vitreum vitreum) sampled with experimental gill nets in Lake Sakakawea, North Dakota (Figure 1). The Lake Sakakawea walleye population is a relatively steady-state population with relatively consistent recruitment (either from stocked or wild fish), growth, and mortality rates (Mero, 1992).

In contrast, seasonal trends in sampling data are often difficult to discern in populations with substantial variations in recruitment, growth, or mortality. For example, Guy and Willis (1991) documented typical seasonal variation in CPUE for black crappies (Pomoxis nigromaculatus) sampled with trap (modified-fyke) nets in Lake Madison, South Dakota (Figure 2). However, size structure (indexed with stock density indices; see review by Willis et al., 1993) did not exhibit expected seasonal peaks during the spring and fall because of inconsistent recruitment in the Lake Madison black crappie population. Instead, proportional stock density (PSD, percent of stock-length [ $\geq 13 \mathrm{~cm}$ for black crappies] fish that are also quality length [ $\geq 20 \mathrm{~cm}$ for black crappies]; Anderson, 1976) for the black crappies was 3 in the spring and increased to 100 by fall due to the growth of a single cohort (age 2) that represented nearly the entire adult population (Figure 2). These lengths, and all subsequent lengths reported in this article, are maximum total length (Anderson and Gutreuter, 1983) - from the anterior end of the fish to the furthest point on the compressed caudal lobes of the fish.

Thus, it is important to distinguish between relatively steady-state populations and populations with erratic recruitment, growth, or mortality. In steady-state populations, recruitment and growth offset losses of adult fish to mortality. In the rest of this article, we focus on seasonal trends in CPUE, size and age structure, growth, and condition for relatively steady-state populations of fish.

\section{CATCH PER UNIT EFFORT}

The CPUE often provides an index to fish density (Carlander, 1953; Walburg, 1969; Le Cren et al., 1977; Serns, 1982, 1983; Hubert, 1983; Hall, 1986; Gabelhouse, 1987; Schorr and Miranda, 1989; McInerny and Degan, 1993; Crozier and Kennedy, 1994; Hill and Willis, 1994). Care must be taken to distinguish between CPUE for stocklength (Gabelhouse, 1984) fishes and overall CPUE, which is obviously affected by 

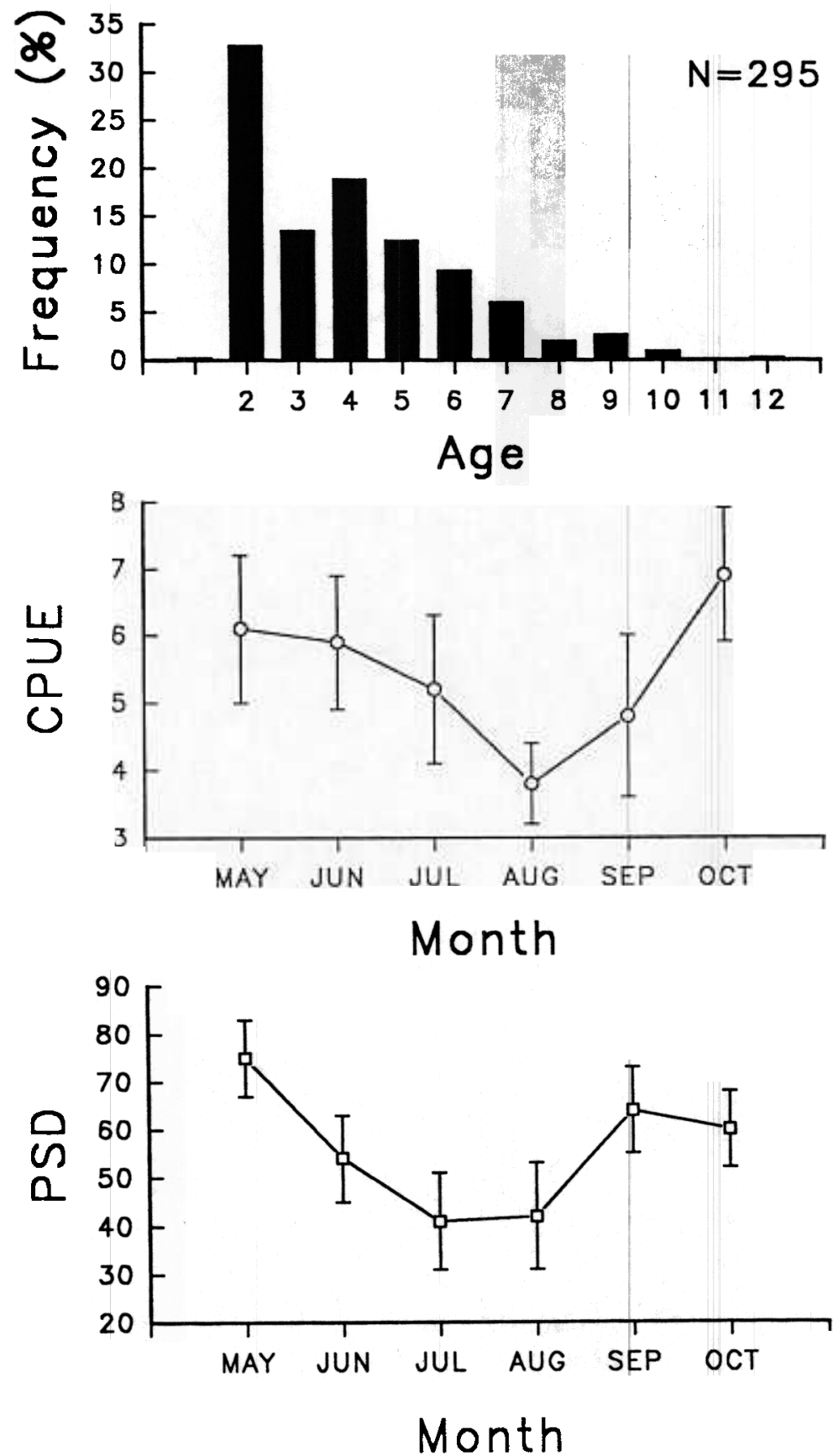

FIGURE 1. Age-frequency histogram (relative frequency), mean catch per unit effort (CPUE \pm SE; catch per net night) for stock-length ( $\geq 25 \mathrm{~cm}$ ) fish, and proportional stock density (PSD $\pm 80 \%$ confidence intervals) for walleyes collected from Lake Sakakawea, North Dakota, during 1991 using experimental gill nets. Age frequency was constructed from spring (May-June) sampling from three different reservoir sites (Mero, 1992). Mean CPUE and PSD are from Mero and Willis (1992). 


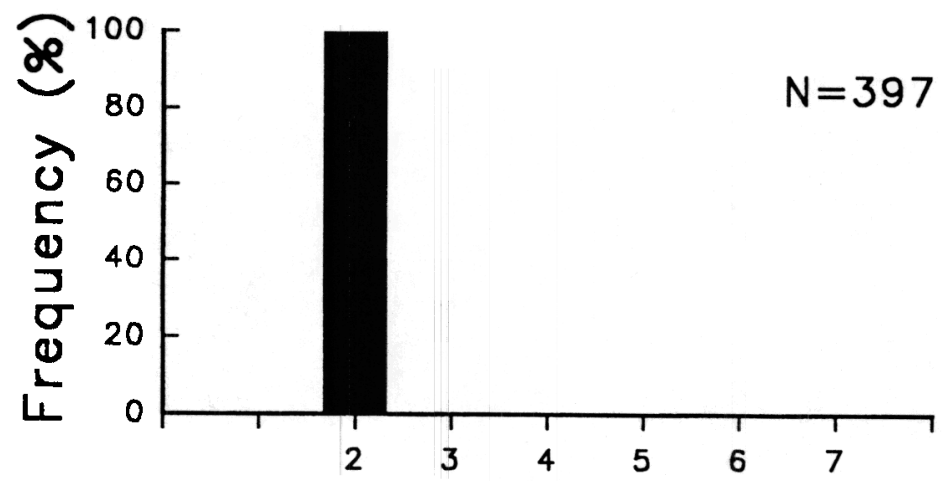

Age
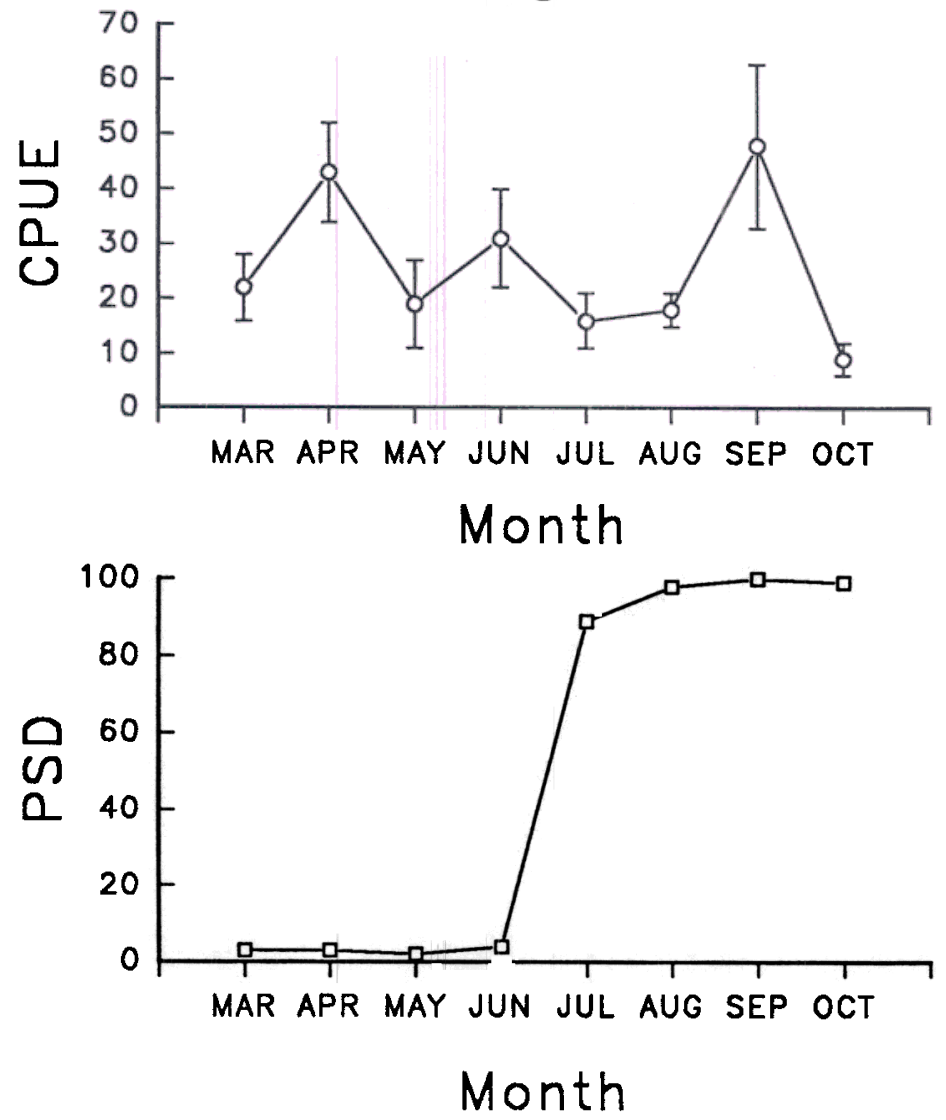

FIGURE 2. Age-frequency histogram (relative frequency), mean catch per unit effort (CPUE \pm SE; catch per net night) for stock-length $(\geq 25 \mathrm{~cm}$ ) fish, and proportional stock density (PSD) for black crappies collected from Lake Madison, South Dakota, during 1990 using trap nets. It is inappropriate to calculate confidence intervals for PSD values of 0 and 100; however, sample size ranged from 158 to 979 each month. Age frequency is from spring (May-June) sampling (Guy and Willis, 1994). Mean CPUE and PSD are from Guy and Willis (1991) and Willis et al. (1993), respectively. 
the recruitment of juveniles to catchable size as the season progresses. These juveniles may or may not eventually recruit to the adult (i.e., reproducing) stock.

The CPUE of stock-length fishes in many freshwater fish populations typically peaks during the spring and fall. For example, the CPUE of stock-length crappies (Pomoxis spp.) in trap nets typically peaks in the spring and fall (Kelley, 1953; Congdon, 1968; Boxrucker and Ploskey, 1988; McInerny, 1988; Guy and Willis, 1991). The mean CPUE of white bass (Morone cbrysops) caught in trap nets from the upper Mississippi River also peaked in the spring and fall (Kelley, 1953). Hamley and Howley (1985) documented spring and fall peaks in trap-net CPUE of white bass, quillback (Carpiodes cyprinus), common carp (Cyprinus carpio) and goldfish (Carassius auratus) combined, brown (Ictalurus nebulosus) and yellow bullheads (I. natalis) combined, and channel catfish (I. punctatus).

This trend in trap-net CPUE of stock-length fishes is likely influenced by fish behavior. Crappies commonly move inshore in the spring to spawn, move offshore during the summer, and return to near-shore areas during the fall (Markham et al., 1991; Guy et al., 1994). Thus, they are more vulnerable to trap nets during the spring and fall when they are near shore. Further, Muoneke et al. (1993) found that the CPUE of white crappies, captured with cylindrical hoop nets set in water about $1.5 \mathrm{~m}$ deeper than a trap net would be set, peaked during the summer when the fish were offshore. Hall and Werner (1977) also noted a general dispersion of fishes from the shallow waters of lakes and reservoirs to deeper waters during the summer.

In addition, summer offshore movement has been documented for largemouth bass in Wisconsin, Illinois, and Iowa (Parker and Hasler, 1959; Lewis and Flickinger, 1967; Van Den Avyle, 1976). The mean CPUE of electrofished largemouth bass in Arbuckle Reservoir and Lake Thunderbird, Oklahoma (Gilliland, 1985), and Big Stone Power Plant cooling pond, South Dakota (Bettross and Willis, 1988; Bettross, 1989), showed spring and fall peaks. Carline et al. (1984) also observed spring and fall peaks in the CPUE for quality-length $(\geq 300 \mathrm{~mm})$ largemouth bass in Ohio impoundments. While electrofishing the littoral zone of Lake Texoma, Gelwick and Matthews (1990) documented spring and fall peaks in CPUE for red shiners (Cyprinella lutrensis), blacktail shiners ( $C$. venusta), and white crappies ( $P$. annularis).

The CPUE of many freshwater fishes caught in gill nets can also peak during the spring and fall. Such a pattern has been documented for the mean experimental gill-net CPUE of walleyes in Elephant Butte Lake, New Mexico (Jester, 1971), walleyes and saugers ( $S$. canadense) in Lake Sakakawea, North Dakota (Mero and Willis, 1992), black bullheads (I. melas) in Lake Poinsett, South Dakota (Congdon, 1968), and striped bass (M. saxatilis) in Lake Texoma, Oklahoma-Texas (Matthews et al., 1989). Also, spring and fall peaks in the mean CPUE for walleye and sauger caught with sinking gill nets in the Norris Reservoir, Tennessee, have been documented (Fitz and Holbrook, 1978). Gill-net catches of common carp in wetlands on national wildlife refuges also exhibited a spring peak in CPUE, while no sampling was conducted in the fall (Clark et al., 1991). Aadland (1987) found that the catch rates of chinook salmon (Oncorbynchus tshawytscba) captured with suspended monofilament gill nets in Lake Sakakawea, North Dakota, increased steadily from June through August. 
Barwick (1984) found that cove rotenone samples collected from a power plant cooling reservoir in South Carolina had a higher estimated fish standing crop in May than in August for several years. He hypothesized that fishes moved to deeper water during the summer and remained there during the late summer sampling because dissolved oxygen did not become limiting in the deeper waters.

Use of angler-collected data is becoming more popular and prevalent in fisheries management (Guthrie et al., 1991). Angling data are also influenced by seasons. For example, angling catches of trophy-size largemouth bass $(\geq 3.2 \mathrm{~kg})$, smallmouth bass (M. dolomieu) $(\geq 1.8 \mathrm{~kg})$, and walleye $(\geq 3.6 \mathrm{~kg})$ peaked during the spring and fall in Iowa (Waters, 1987). Trophy crappies $(\geq 0.9 \mathrm{~kg})$ showed a late spring peak in angling catches. Angling catches of trophy bluegills (Lepomis macrochirus) $(\geq 0.5 \mathrm{~kg})$ peaked in late spring and again in summer. Peak catches of trophy muskellunge (Esox masquinongy) ( $\geq 102 \mathrm{~cm}$ or $6.8 \mathrm{~kg}$ ) occurred during late summer and early fall. Peak angler catches of trophy channel $(\geq 6.8 \mathrm{~kg}$ ) and flathead catfish (Pylodictis olivaris) ( $\geq 9.1 \mathrm{~kg}$ ) occurred during the summer. Waters (1987) reported catches for trophy fish, not CPUE. Thus, the patterns in seasonal angling catches in Iowa could also be a reflection of seasonal changes in angling effort rather than changes in fish behavior.

However, peak angler CPUE for all sizes of crappies and sunfish (i.e., bluegills, yellow perch [Perca flavescens], pumpkinseed [L. gibbosus], and bullheads) peaked during June, declined in late summer, and remained low during the fall in a southeastern Minnesota natural lake (Lux and Smith, 1960). Lux and Smith (1960) reported a significant inverse correlation between angler success (i.e., angler CPUE for sport fishes) and food availability for fishes, which increased in late summer and remained high for the fall.

Although the general seasonal trend in the CPUE of stock-length fishes involves spring and fall peaks, exceptions are common. Some species may not show both peaks in CPUE or may even show a different peak in CPUE when collected by a certain gear type. For example, Ryan (1984) reported that the catchability of Atlantic salmon (Salmo salar) in fyke nets was higher in spring than in fall. Hansen (1953) reported a spring-only CPUE peak for largemouth bass caught in hoop nets at Lake Glendale, IL, while bluegill hoop-net CPUE values were highest in the spring and then declined through the summer and into the fall. However, hoop-net CPUE for bluegill $\times$ green sunfish (L. cyanellus) hybrids peaked during the summer (Hansen, 1953). Kruse (1993) found no seasonal trend in the trap-net CPUE for bluegills in two Missouri impoundments; CPUE did not differ across the spring, summer, and fall. The CPUE of stock-length walleyes $(\geq 25 \mathrm{~cm})$ and black crappies caught in trap nets in Lake Madison, South Dakota, peaked during the spring and fall and also showed a smaller summer peak (Guy and Willis, 1991). Similarly, trap net catches of stock-length white and black crappies in the upper Mississippi River showed spring and fall peaks in CPUE, with an additional summer peak (Kelley, 1953). However, the trap-net CPUE of white crappies in Lake Carl Blackwell, Oklahoma, peaked during the winter (Muoneke et al., 1993).

The CPUE of stock-length ( $\geq 35 \mathrm{~cm}$ ) northern pike (E. lucius) commonly has a spring peak, but not a fall peak (Kelley, 1953; Dahlberg, 1981; Guy and Willis, 1991; Neumann and Willis, 1995). Cook and Bergersen (1988) also observed a spring peak in the gill-net CPUE for northern pike and correlated the peak CPUE with peak northern pike activity during the spring as determined by biotelemetry. Trout-perch 
(Percopsis omiscomaycus) collected with experimental gill nets also showed a spring-only peak in CPUE, which was associated with their spawning activity (Dahlberg, 1981).

The CPUE of stock-length $(\geq 13 \mathrm{~cm}$ ) yellow perch caught with experimental gill. nets in South Dakota natural lakes was higher during the summer than the spring (Lott, 1991), while the CPUE of stock-length yellow perch in trap nets in Lake Madison, South Dakota, peaked only in the summer (Guy and Willis, 1991). The CPUE of all yellow perch (age-0 and age-1 yellow perch accounted for $43 \%$ of the catch) caught using experimental gill nets with mesh sizes ranging from 1.27 to 8.89 $\mathrm{cm}$ (bar measure) in Cayuga Lake, New York, was highest during the summer and fall (Dahlberg, 1981).

The gill-net CPUE of age 1 and older alewife (Alosa pseudobarengus) in Cayuga Lake, New York, peaked during the summer when the alewife moved inshore to spawn. Once spawning ended, the alewife returned to a more limnetic habitat and the gill-net CPUE declined (Dahlberg, 1981). The gill-net CPUE for both channel catfish and white bass peaked during the summer in Elephant Butte Lake, New Mexico (Jester, 1971), and during late summer in McConaughy Reservoir, Nebraska (McCarraher et al., 1971).

The CPUE of bluegills ( $\geq 70 \mathrm{~mm}$ ) caught with a bottom trawl in Lake Wingra, Wisconsin, only peaked in the fall (Baumann and Kitchell, 1974). The otter-trawl CPUE of adult ( $\geq$ age 3) yellow perch in Oneida Lake, New York, peaked during the summer and again during the fall, while no sampling occurred in the spring (Nielsen, 1983).

Hubert and O'Shea (1991) reported a variable summer CPUE for 11 fish species sampled by seining the littoral zone of Grayrocks Reservoir, Wyoming. Also, Mayhew (1973) reported that the CPUE for channel catfish and common carp in baited hoop nets in the Des Moines River, Iowa, increased through the summer, peaked in late summer, and then declined in early fall. Hubert and Schmitt (1982) found significant differences between sampling periods (approximately 2-week intervals) for the CPUE of black crappie, freshwater drum (Aplodinotus grunniens), flathead catfish, smallmouth buffalo (Ictiobus bubalus), and shorthead redhorse (Moxostoma macrolepidotum) sampled with hoop nets in the upper Mississippi River from July through October.

Age 0 fishes hatched in the spring or summer typically are not sampled with common freshwater fisheries gear (i.e., electrofishing, trap nets, or gill nets) during the spring and usually not during the summer. Thus, the CPUE of age 0 fishes will usually peak in the fall and will add to the overall CPUE of a fish species during the fall. Boxrucker and Ploskey (1988) reported that age 0 crappies were captured in trap nets during the fall, but not in the spring when they were larval fish. Miranda et al. (1990) found a higher trap-net CPUE during the fall for white crappies that were $<20 \mathrm{~cm}$ long. Braaten (1993) also found an increase in the catch rates of small ( 30 to $75 \mathrm{~mm}$ ) age 0 channel catfish between July and August as these fish recruited to his gear (an electric seine). Once again, the expected peak in CPUE in the fall for age 0 fishes does not always occur. For example, the estimated biomass of age 0 yellow perch in Oneida Lake, New York, peaked in mid-summer and then declined in the fall as a result of high mortality (Mills and Forney, 1983; Mills et al., 1987). 


\section{SIZE AND AGE STRUCTURE}

Size and age structure analyses provide insights about the status of a fish population. Biased sampling data can result in biased size and age structures, which will affect the calculation of other population parameters. For example, if the age structure of a population is underestimated (i.e., the proportion of older individuals captured is lower than the true proportion in the population, while the proportion of younger individuals captured is greater than the true proportion in the population), the mortality rate calculated by the catch-curve method (Ricker, 1975) for the population will be overestimated and may lead to incorrect management decisions.

Along with seasonal variation in the CPUE of stock-length fish, size and age structure vary seasonally primarily due to differences in CPUE over the seasons for various sizes and ages of fish. Size structure, often conveniently quantified by PSD or other stock density indices such as relative stock density (RSD; Wege and Anderson, 1978), commonly peaks during the spring and fall. Along with size structure, age structure (estimated by mean age) also peaks during the spring and fall, as larger fish typically also are older fish.

Spring and fall peaks in PSD have been observed for bluegills collected with trap nets and by electrofishing in South Dakota (Bettross and Willis, 1988). Peaks in PSD during the spring and fall for largemouth bass collected by electrofishing have been reported in Ohio, Oklahoma, and South Dakota (Carline et al., 1984; Gilliland, 1985; Bettross and Willis, 1988). Mesa et al. (1990) also found a spring peak in PSD for electrofished smallmouth bass with a summer decline in PSD, but did not sample during the fall. Spring and fall peaks in PSD have also been reported for gill-net catches. For example, PSD peaked during the spring and fall for yellow perch (Lott and Willis, 1991) and walleyes and saugers (Mero and Willis, 1992) collected with experimental gill nets.

Miranda et al. (1990) documented differences in the young-to-adult ratio (YAR; Reynolds and Babb, 1978) for spring and fall samples of white crappies. They found that YAR estimates were higher in the fall when either trap nets or electrofishing were used to sample white crappies.

There are many unique cases that differ from the typical spring and fall peaks in size and age structure. For example, size structure may fluctuate within a season. Serns (1985) noted that the PSD of walleyes sampled during spawning with fyke nets was low early and late during the spawning season because smaller males were abundant on the spawning grounds during those times. The PSD was high during the middle of the spawning period because larger females were most abundant at that time.

In addition, size and age structure may differ between spring and fall. Boxrucker and Ploskey (1988) found greater proportions of age 2 and older white crappies collected in spring trap nets than were collected in the fall. McInerny (1988) also found the RSD of preferred-length (RSD-P; percent of stock-length fish that are also preferred length) black crappies caught in trap nets to be higher in the spring than in the fall. Malvestuto and Sonski (1990) found differences between fall daytime and nighttime PSD for electrofished largemouth bass on West Point Reservoir, AlabamaGeorgia, with the PSD lower at night due to an influx of stock-to-quality-length (20 to $30 \mathrm{~cm}$ ) largemouth bass to the shoreline at night. 
Finally, Neumann and Willis (in press) found that the PSD for northern pike collected with experimental gill nets on the southern edge of their native range (South Dakota) peaked in the winter and declined into the summer. They suggested that the seasonal change in PSD for northern pike may be attributed to sex- and sizerelated differences in activity and habitat use and reported a higher male:female catch ratio in summer than in winter.

\section{GROWTH}

Growth is a long-term indicator of fish population status and is highly influenced by the length of the growing season. Growth of many freshwater fishes occurs during the summer. For example, an Alberta northern pike population showed a length increase during the summer (Diana and Mackay, 1979), and Ontario northern pike had the highest instantaneous growth rates during early summer (Casselman, 1987, 1990). White crappies in Melvern Reservoir, Kansas (Gabelhouse, 1991), and in Lake Goldsmith, South Dakota (Guy and Willis, 1995), had the highest mean growth increments during the summer. Willis et al. (1993) reported that black crappies in Lake Madison, South Dakota, attained most of their growth in length during the summer. Alexander and Shetter (1961) documented increases in the length and weight of stocked rainbow trout (O. mykiss) and brook trout (Salvelinus fontinalis) in Michigan during the spring, summer, and fall, while length and weight remained relatively constant during the winter. Gerking (1966) found that growth of bluegills occurred in the spring, summer, and fall, but not in the winter.

There are also exceptions to the general trend in seasonal growth of fish. For example, winter growth of northern pike has been documented (Diana and Mackay, 1979; Diana, 1983; Headrick and Carline, 1993; Neumann et al., 1994). In addition, northern pike on the southern edge of their native range have shown a reduction in growth (Headrick and Carline, 1993; Neumann et al., 1994) and food consumption (Sammons et al., 1994) during warm summer months.

\section{CONDITION}

Condition is a short-term indicator of fish health status and is primarily influenced by food availability and gonadal growth. Typically with spring spawners, fish condition is highest in the spring just before spawning, declines immediately after spawning, then increases through the summer and into the fall. Guy and Willis (1991) documented seasonal variation in the mean relative weight (Wr; Wege and Anderson, 1978; see also review in Murphy et al., 1991) for northern pike, black crappies, yellow perch, and walleyes captured with trap nets in Lake Madison, South Dakota. In general, the mean $\mathrm{Wr}$ declined from spring to early summer and then increased until early fall. Gabelhouse (1991) found that the $\mathrm{Wr}$ of 250 - to $299-\mathrm{mm}$ white crappies in Melvern Reservoir, Kansas, was high during the prespawn period, declined after spawning, and then increased throughout the summer and fall. Neumann and Murphy (1992) found the same seasonal trend for white crappies in Texas, while Neumann and Murphy (1991) reported similar seasonal trends in Wr for black crappies. Brown (1993) reported similar seasonal trends in Wr for quality- 
to preferred-length (Q-P; 30 to $38 \mathrm{~cm}$ ) largemouth bass in Aquilla Lake, Texas. Le Cren (1951) found similar seasonal patterns in body condition for Eurasian perch $(P$. fluviatilis). Frost and Kipling (1967) used two different weight-length regressions when analyzing the summer and winter condition of mature northern pike, with the winter condition expected to be higher due to ripening gonads.

Obviously, the seasonal trend in condition for fish species that spawn in the summer (e.g., bluegill) or fall (e.g., brook and brown trout [Salmo trutta]) should be different than spring spawners. Legler (1977) reported that the $\dot{\mathrm{W}} r$ of bluegills peaked in early summer and then declined throughout the spawning and growing season (i.e., summer). Benson (1953) measured the seasonal coefficient of condition, $\mathrm{R}$ (Cooper and Benson, 1951), for brook trout in the Pigeon River, Michigan. He found that condition peaked during spting, remained high through early summer, and then declined into late summer and fall. Along with the decline in $\mathrm{R}$ in late summer and fall, the mean volume of stomach contents also declined (Benson, 1953).

In addition, differences in gonadal development between males and females may show different seasonal trends in fish condition. For example, northern pike testicular growth occurs during the fall (Diana and Mackay, 1979; Neumann and Willis, 1995), while ovarian growth begins in the fall and continues up to the time of spawning (Neumann and Willis, 1995).

Fish size may also affect the seasonal trend in fish condition. For example, Neumann and Murphy (1991) observed that the Wr of smaller $(<200 \mathrm{~mm})$ black crappies was highest in the spring and continued to decline into the fall. Gabelhouse (1991) also found that 130- to 199-mm white crappies in Melvern Reservoir, Kansas, exhibited the highest $\mathrm{Wr}$ in July, and that Wr continued to decline throughout the fall and winter. Hansen (1951) found that crappies $<165 \mathrm{~mm}$ reached peak body condition in June and July and declined afterwards. However, Brown (1993) reported that smaller (125 to $300 \mathrm{~mm}$ ) largemouth bass in Aquilla Lake, Texas, came out of the winter with a low Wr (i.e., 85), and condition remained low until late spring-early summer, when $\mathrm{Wr}$ increased (i.e., 105).

Le Cren (1951) noted that seasonal changes in the condition of mature fish are due to changes in gonad weight. However, seasonal changes in the condition of immature fish may be attributable to feeding conditions throughout the winter and spring. Gabelhouse (1991) speculated that the summer peak condition of small white crappies in Melvern Reservoir reflected the feeding conditions associated with peak spawning of gizzard shad (Dorosoma cepedianum) in mid to late May.

\section{GEAR CONSIDERATIONS}

Gear-related biases are a problem with which fisheries managers must often deal. Problems with gear-related biases can be minimized for long-term data sets by using standardized sampling (i.e., sampling at the same time of the year and using the same gear and effort). This allows managers to identify long-term trends in a fish population because gear-related biases should be relatively consistent from year to year. However, interpretation of nonstandardized sampling data can be difficult because two different biases (i.e., seasonal influences and gear-related biases) are occurring at the same time. Thus, when analyzing nonstandardized sampling data, 
fisheries managers must understand how seasonal influences and gear-related biases individually affect fisheries sampling data.

Gear-related biases often influence CPUE, and estimates of size and age structure. For example, Forney (1961) found that trap nets selected for older age groups of walleye during the fall in Onedia Lake, New York, while spring trap net samples captured walleyes of various age groups in proportion to their abundance. However, age distributions of mature walleyes captured by other gears (i.e., electrofishing, trawling, and gill netting) were similar between spring, summer, and fall. Laarman and Ryckman (1982) found that trap nets set in September and October selected for larger sizes of rock bass (Ambloplites rupestris), walleye, black crappie, bluegill, yellow perch, and pumpkinseed; they did not find significant size selectivity of trap nets for smallmouth bass or white suckers (Catostomus commersoni).

The electrofishing CPUE is not only affected by the season of sampling, but can also be affected by the time (i.e., day or night) of sampling. Nighttime electrofishing CPUE values are often higher than daytime values (Paragamian, 1989; Sanders, 1992). However, while Bennett and Brown (1969) found increased nighttime electrofishing CPUE for redear sunfish ( $L$. microlopbus), they found no difference in daytime and nighttime electrofishing CPUE values, both by number and by weight, for bluegills, warmouths (L. gulosus), and largemouth bass. Furthermore, Malvestuto and Sonski (1990) reported no difference in daytime and nighttime electrofishing CPUE, by number, for largemouth bass during spring and fall, but did find higher CPUE for nighttime electrofishing during the summer.

Electrofishing samples can also have size-related biases. Reynolds and Simpson (1978) reported that electrofishing effectiveness increased with increasing length of largemouth bass; however, they noted that the overestimation in size structure was slight when only stock-length ( $\geq 200 \mathrm{~mm}$ ) largemouth bass were considered. In contrast, electrofishing underestimated the size structure for bluegill (Reynolds and Simpson, 1978) and smallmouth bass (Milewski and Willis, 1991) populations (i.e., electrofishing effectiveness decreased with increasing length of bluegill and smallmouth bass). Furthermore, the time of day for electrofishing may also influence the estimated size structure of a fish population. Paragamian (1989) found that the PSD for spring electrofished smallmouth bass was higher at night. Sauger size structure was higher during day electrofishing than at night in turbid Lewis and Clark Lake, South Dakota/Nebraska (Van Zee et al., 1996).

Gill net mesh-size selectivity causes small fish to be less effectively sampled than large fish in experimental gill nets (Hamley, 1975). Thus, size and age structure are likely overestimated for most fish species collected with experimental gill nets. Furthermore, overestimation of age structure will lead to incorrect estimates for other population parameters (e.g., underestimation of annual mortality rates).

\section{IMPLICATIONS}

Our primary purpose was to summarize available information on seasonal trends in freshwater fisheries sampling data, including an extensive literature review. In this way, we hoped to provide a better awareness of sampling and data analysis problems that can be caused by seasonal variability in sampling parameters. 
CPUE, size and age structure, growth, and condition of fishes should be expected to change with season; such changes should be easily observed in steadystate populations. Managers and researchers should take into consideration seasonal patterns when collecting and analyzing their data. At the least, both research biologists and management biologists should utilize standardized sampling (sampling at similar times with similar gears each year). Even if indices or estimates are biased because of the chosen sampling date or sampling gear, changes over time should be apparent if the sampling is standardized.

It might seem appropriate to make recommendations for optimum sampling times for at least some fish species. However, we hesitate to generalize because we found substantial differences among geographic locations and an insufficient number of thorough assessments. Much is known about seasonal trends in sampling data for largemouth bass collected by electrofishing and crappies collected with trap nets in midwestern impoundments. However, we wonder how far north (i.e., latitude) a biologist would have to travel before single midsummer peaks in CPUE and size structure would be evident. We might expect such single peaks if there is a brief, relatively cool summer with cold water temperatures during the "spring" and "fall" time periods. In reality, the single peaks might simply coincide with the spawning period for "spring" spawners.

Seasonal patterns should not necessarily be assumed to be the same for different species or for species in different habitats or geographic regions because differences may exist (1) in recruitment, growth, and mortality within a species, (2) among species, (3) among geographic locations, (4) among different water body types, and (5) among gears used in sampling. Certainly, we believe more research on some species within certain environments is justified. For example, little evaluation of seasonal trends in sampling data has been accomplished for cold-water species such as the salmonids.

\section{ACKNOWLEDGMENTS}

Reviews of earlier drafts of this manuscript were provided by Michael Brown, Stephen Flickinger, Wayne Hubert, Todd Marwitz, Robert Mauk, and Brian Murphy. This manuscript was approved for publication by the South Dakota Agricultural Experiment Station as Journal Series Number 2844.

\section{REFERENCES}

Aadland, L. P. Food Habits, Distribution, Age and Growth of Chinook Salmon, and Predation on Newly Stocked Chinook Smolts in Lake Sakakawea, North Dakota. Ph.D. thesis, University of North Dakota, Grand Forks (1987).

Alexander, G. R. and D. S. Shetter. Seasonal mortality and growth of hatchery-reared brook and rainbow trout in East Fish Lake, Montmorency County, Michigan, 1958-59. Mich. Acad. Sci., 46: 317-328 (1961).

Anderson, R. O. Management of small warm water impoundments. Fisheries (Bethesda), 1(6): 5-7, 26-28 (1976).

Anderson, R. O. and S. J. Gutreuter. Length, weight, and associated structural indicies. In: Fisheries Techniques, pp. 283-300 (Nielsen, L. A. and D. L. Johnson, Eds.). Bethesda: American Fisheries Society (1983). 
Barwick, D. H. Role of fish distribution on estimates of standing crop in $\mid$ a cooling reservoir. North Am. J. Fish. Manage., 4: 308-313 (1984).

Baumann, P. C. and J. F. Kitchell. Diel patterns of distribution and feeding of bluegill (Lepomis macrochirus) in Lake Wingra, Wisconsin. Trans. Am. Fish. Soc., 103: 255-260 (1974).

Bennett, C. D. and B. E. Brown. A comparison of fish population sampling techniques on Lake Raymond Gary, Oklahoma. Proc. Annu. Conf. Southeast. Assoc. Game Fish Comm., 22: 425-444 (1969).

Benson, N. G. Seasonal fluctuations in the feeding of brook trout in the Pigeon River, Michigan. Trans. Am. Fish. Soc., 83: 76-83 (1953).

Bettross, E. A. and D. W. Willis. Seasonal patterns in sampling data for largemouth bass and bluegills in a northern great plains impoundment. Prairie Nat., 20: 193-202 (1988).

Bettross, E. A. Evaluation of the Big Stone Power Plant Cooling Reservoir as a Source of Largemouth Bass and Bluegill Broodstock. M.S. thesis, South Dakota State University, Brookings (1989).

Boxrucker, J. and G. Ploskey. Gear and seasonal biases associated with sampling crappie in Oklahoma. Proc. Annu. Conf. Southeast. Assoc. Fish Wild. Agencies, 42: 89-97 (1988).

Braaten, P. J. The Influence of Habitat Structure and Environmental Variability on Habitat Use by Fish in the Vermillion River, South Dakota. M.S. thesis, South Dakota State University, Brookings (1993).

Brown, M. L. Temporal Genetic Structure and Energy Dynamics of an Intergrade Largemouth Bass Population. Ph.D. thesis, Texas A\&M University, College Station (1993).

Carlander, K. D. Use of gill nets in studying fish populations, Clear Lake, Iowa, Proc. lowa Acad. Sci., 60: 621-625 (1953).

Carline, R. F., B. L. Johnson, and T. J. Hall. Estimation and interpretation of proportional stock density for fish populations in Ohio impoundments. North Am.J. Fish. Manage., 4: 139154 (1984).

Casselman, J. M. Determination of age and growth. In: The Biology of Fish Growth, pp. 209242. (A. H. Weatherley and H. S. Gill, Eds.). London: Academic Press (1987).

Casselman, J. M. Growth and relative size of calcified structures of fish. Trans. Am. Fish. Soc., 119: 673-688 (1990).

Clark, S. W., D. W. Willis, and C. R. Berry, Jr. Indexing of common carp populations in large palustrine wetlands of the northern plains. Wetlands, 11: 163-172 (1991).

Congdon, J. C. The Fish Population of Lake Poinsett, South Dakota, as Indicated by the Catch of Four Types of Gear. M.S. thesis, South Dakota State University, Brookings (1968).

Cook, M. F. and E. P. Bergersen, Movements, habitat selection, and activity periods of northern pike in Eleven Mile Reservoir, Colorado. Trans. Am. Fish. Soc., 117: 495-502 (1988).

Cooper, E. L. and N. G. Benson. The coefficient of condition of brook, brown, and rainbow trout in the Pigeon River, Otsego County, Michigan. Prog. Fish Cult., 13: 181-192 (1951).

Crozier, W. W. and G. J. A. Kennedy. Application of semiquantitative electrofishing to juvenile salmonid stock surveys. J. Fish Biol., 45: 159-164 (1994).

Dahlberg, M. D. Nearshore spatial distribution of fishes in gill net samples, Cayuga Lake, New York. J. Great Lakes Res., 7: 7-14 (1981).

Diana, J. S. Growth, maturation, and production of northern pike in three Michigan lakes. Trans. Am. Fish. Soc., 112: 38-46 (1983).

Diana, J. S. and W. C. Mackay. Timing and magnitude of energy deposition and loss in the body, liver, and gonads of northern pike (Esox lucius). J. Fish. Res. Board Can., 36: 481487 (1979).

Fitz, R. B. and J. A. Holbrook, II. Sauger and walleye in Norris Reservoir, Tennessee. In: Selected Coolwater Fishes of North America, pp. 82-88 (Kendall, R. L., Ed.). Bethesda: American Fisheries Society, Special Publication Number 11 (1978).

Forney, J. L. Year-class distribution of walleyes collected by five types of gear. Trans. Am. Fish. Soc., 90: 308-311 (1961). 
Frost, W. E. and C. Kipling. A study of reproduction, early life, weight-length relationship and growth of pike, Esox lucius L., in Witdermere. J. Anim. Ecol., 36: 651-693 (1967).

Gabelhouse, D. W., Jr. A length-categorization system to assess fish stocks. North Am. J. Fish. Manage., 4: 273-285 (1984).

Gabelhouse, D. W., Jr. Responses of largemouth bass and bluegills to removal of surplus largemouth bass from a Kansas pond. North Am. J. Fish. Manage., 7: 81-90 (1987).

Gabelhouse, D. W., Jr. Seasonal changes in body condition of white crappies and relations to length and growth in Melvern Reservoir, Kansas. North Am.J. Fish. Manage., 11: 50$56(1991)$.

Gelwick, F. P. and W. J. Matthews. Temporal and spatial patterns in littoral-zone fish assemblages of a reservoir (Lake Texoma, Oklahoma-Texas, U.S.A.). Environ. Biol. Fish., 27: $107-120$ (1990).

Gerking, S. D. Annual growth cycle, growth potential, and growth compensation in the bluegill sunfish in northern Indiana lakes. J. Fish. Res. Board Can., 23: 1923-1956 (1966).

Gilliland, E. Evaluation of Oklahoma's stahdardized electrofishing in calculating population structure indices. Proc. Annu. Conf. Soutbeast. Assoc. Fish Wildl. Agencies, 39: 277-287 (1985).

Guthrie, D., J. M. Hoenig, M. Holliday, C. M. Jones, M. J. Mills, S. A. Moberly, K. H. Pollock, and D. R. Talhelm, Eds. Creel and Angler Surveys in Fisberies Management. Bethesda: American Fisheries Society, Symposium 12 (1991).

Guy, C. S. and D. W. Willis. Seasonal variation in catch rate and body condition for four fish species in a South Dakota natural lake. J. Freshwater Ecol., 6: 281-292 (1991).

Guy, C. S. and D. W. Willis. Relationships between crappie populations and environmental conditions in South Dakota waters. Pierre, SD: South Dakota Department of Game, Fish and Parks, Completion Report 94-3 (1994).

Guy, C. S. and D. W. Willis. Growth of crappies in South Dakota waters. J. Freshwater Ecol., 10: 151-161 (1995).

Guy, C. S., D. W. Willis, and J. J. Jackson, Biotelemetry of white crappies in a South Dakota glacial lake. Trans. Am. Fish. Soc., 123: 63-70 (1994).

Hall, D. J. and E. E. Werner. Seasonal distribution and abundance of fishes in the littoral zone of a Michigan lake. Trans. Am. Fish. Soc., 106: 545-555 (1977).

Hall, T. J. Electrofishing catch per hour as an indicator of largemouth bass density in Ohio impoundments. North Am. J. Fish. Manage., 6: 397-400 (1986).

Hamley, J. M. Review of gillnet selectivity. J. Fish. Res. Board Can., 32: 1943-1969 (1975).

Hamley, J. M. and T. P. Howley. Factors affecting variability of trapnet catches. Can. J. Fish. Aquat. Sci., 42: 1079-1087 (1985).

Hansen, D. F. Biology of the white crappie in Illinois. Il. Nat. Hist. Survey. Bull., 25: 211-265 (1951). Hansen, D. F. Seasonal variation in hoop het catches at Lake Glendale. Trans. Il. Acad. Sci.,
46: 216-226 (1953).

Headrick, M. R. and R. F. Carline. Restricted summer habitat and growth of northern pike in two southern Ohio impoundments. Trans. Am. Fish. Soc., 122: 228-236 (1993).

Hill, T. D. and D. W. Willis. Influence of water conductivity on pulsed AC and pulsed DC electrofishing catch rates for largemouth bass. North Am. J. Fish. Manage., 14: 202-207 (1994).

Hubert, W. A. Passive capture techniques. In: Fisberies Tecbniques, pp. 95-122 (Nielsen, L. A. and D. L. Johnson, Eds.). Bethesda: American Fisheries Society (1983).

Hubert, W. A. and D. T. O'Shea. Temporal patterns of the small fishes in the littoral zone of Grayrocks Reservoir, Wyoming. J. Freshwater Ecol., 6: 107-113 (1991).

Hubert, W. A. and D. N. Schmitt. Factors influencing hoop net catches in channel habitats of Pool 9, upper Mississippi River. Proc. Iowa Acad. Sci., 89: 84-88 (1982). 
Jester, D. B. Effects of color, mesh size, fishing in seasonal concentrations, and baiting on catch rates of fishes in gill nets. Trans. Am. Fish. Soc., 106: 43-56 (1971).

Kelley, D. W. Fluctuation in trap net catches in the upper Mississippi River. Washington, D.C.: U.S. Fish and Wildlife Service, Special Scientific Report, Fisheries Number 101 (1953).

Kruse, M. S. An Evaluation of Bluegill Sampling Methods. Missouri Department of Conservation, Dingell-Johnson Project F-1-R-42, Study I-29, Job 1, Final Report (1993).

Laarman, P. W. and J. R. Ryckman. Relative size selectivity for eight species of fish. North Am. J. Fish. Manage., 2: 33-37 (1982).

Le Cren, E. D. The length-weight relationship and seasonal cycle in gonad weight and condition in the perch (Perca fluviatilis L.). J. Anim. Ecol., 20: 201-219 (1951).

Le Cren, E. D., C. Kipling, and J. C. McCormack. A study of the numbers, biomass and yearclass strengths of perch (Perca fluviatilis) in Windermere from 1941 to 1966. J. Anim. Ecol., 46: 281-307 (1977).

Legler, R. E. New Indices of Well-Being for Bluegills. M.S. thesis, University of Missouri, Columbia (1977).

Lewis, W. M. and S. Flickinger. Home range tendency of the largemouth bass (Micropterus salmoides). Ecology, 48: 1020-1023 (1967).

Lott, J. P. Food Habits of Yellow Perch in Eastern South Dakota Glacial Lakes. M.S. thesis, South Dakota State University, Brookings (1991).

Lott, J. P. and D. W. Willis. Gill net mesh size efficiency for yellow perch. Prairie Nat., 23: 139-144 (1991)

Lux, F. E. and L. L. Smith, Jr. Some factors influencing seasonal changes in angler catch in a Minnesota lake. Trans. Am. Fish. Soc., 89: 67-79 (1960).

Malvestuto, S. P. and B. J. Sonski. Catch rate and stock structure: a comparison of daytime versus night-time electric fishing on West Point Reservoir, Georgia, Alabama. In: Developments in Electric Fishing, pp. 210-218 (Cowx, I. G., Ed.). Oxford: Blackwell Scientific (1990).

Markham, J. L., D. L. Johnson, and R. W. Petering. White crappie summer movements and habitat use in Delaware Reservoir, Ohio. North Am. J. Fish. Manage., 11: 504-512 (1991).

Matthews, W. J., L. G. Hill, D. R. Edds, and F. P. Gelwick. Influence of water quality and season on habitat use by striped bass in a large southwestern reservoir. Trans. Am. Fish. Soc., 118: 243-250 (1989).

Mayhew, J. Variations in the catch success of channel catfish and carp in baited hoop nets. Proc. Iowa Acad. Sci., 80: 136-139 (1973).

McCarraher, D. B., M. L. Madsen, and R. E. Thomas. Ecology and fishery management of McConaughy Reservoir, Nebraska. Am. Fish. Soc. Spec. Publ., 8: 299-311 (1971).

McInerny, M. C. Evaluation of trapnetting for sampling black crappie. Proc. Annu. Conf. Soutbeast. Assoc. Fish Wildl. Agencies, 42: 98-106 (1988).

McInerny, M. C. and D. J. Degan. Electrofishing catch rates as an index of largemouth bass population density in two large reservoirs. North Am. J. Fish. Manage., 13: 223-228 (1993).

Mero, S. W. Food Habits of Walleye and Sauger in Lake Sakakawea, North Dakota. M.S. thesis, South Dakota State University, Brookings (1992).

Mero, S. W. and D. W. Willis. Seasonal variation in sampling data for walleye and sauger collected with gill nets from Lake Sakakawea, North Dakota. Prairie Nat., 24: 231-240 (1992).

Mesa, M. G., S. D. Duke, and D. L. Ward. Spatial and temporal yariation in proportional stock density and relative weight of smallmouth bass in a reservoir. J. Freshwater Ecol., 5: 323339 (1990).

Milewski, C. L. and D. W. Willis. Smallmouth bass size structure and catch rates in five South Dakota lakes as determined from two sampling gears. Prairie Nat., 23: 53-60 (1991). 
Mills, E. L. and J. L. Forney. Impact on Daphnia pulex of predation by young yellow perch in Oneida Lake, New York. Trans. Am. Fish. Soc., 112: 154-161 (1983).

Mills, E. L., D. M. Green, and A. Schiavone, Jr. Use of zooplankton size to assess the community structure of fish populations in freshwater lakes. North Am.J. Fish. Manage., 7: 369-378 (1987).

Miranda, L. E., J. C. Holder, and M. S. Schorr. Comparison of methods for estimating relative abundance of white crappie. Proc. Annu. Conf. Soutbeast. Assoc. Fish Wildl. Agencies, 44: 89-97 (1990).

Muoneke, M. I., O. E. Maughan, and C. C. Henry. Comparative capture efficiencies of frame and hoop nets for white crappie (Pomoxis annularis Rafinesque). Fish. Res., 18: 231-240 (1993).

Murphy, B. R., D. W. Willis, and T. A. Springer. The relative weight index in fisheries management: status and need. Fisheries (Bethesda), 16(2): 30-38 (1991).

Neumann, R. M. and B. R. Murphy. Evaluation of the relative weight ( $W r$ ) index for assessment of white crappie and black crappie populations. North Am.J. Fish. Manage., 11: 543-555 (1991).

Neumann, R. M. and B. R. Murphy. Seasonal relationships of relative weight to body composition in white crappie, Pomoxis annularis Rafinesque. Aquat. Fish. Manage., 23: 243-251 (1992).

Neumann, R. M., D. W. Willis, and S. M. Sammons. Seasonal growth of northern pike (Esox lucius) in a South Dakota glacial lake. J. Freshwater Ecol., 9: 191-196 (1994).

Neumann, R. M. and D. W. Willis. Seasonal variation in gill-net sample indexes for northern pike collected from a glacial prairie lake. North Am.J. Fish. Manage., 15: 838-844 (1995).

Nielsen, L. A. Variation in the catchability of yellow perch in an otter trawl. Trans. Am. Fish. Soc., 112: 53-59 (1983).

Paragamian, V. L. A comparison of day and night electrofishing: size structure and catch per unit effort for smallmouth bass. North Am. J. Fish. Manage., 9: 500-503 (1989).

Parker, R. A. and A. D. Hasler. Movements of some displaced centrarchids. Copeia, 1959: 1118 (1959).

Reynolds, J. B. and L. R. Babb. Structure and dynamics of largemouth bass populations. In: New Approaches to the Management of Small Impoundments, pp. $50-61$ (Novinger, G. D., and J. G. Dillard, Eds.). Bethesda: North Central Division, American Fisheries Society, Special Publication Number 5 (1978).

Reynolds, J. B. and D. E. Simpson. Evaluation of fish sampling methods and rotenone census. In: New Approacbes to the Management of Small Impoundments, pp. 11-24 (Novinger, G. D. and J. G. Dillard, Eds.). Bethesda: North Central Division, American Fisheries Society, Special Publication Number 5 (1978).

Ricker, W. E. Computation and interpretation of biological statistics of fish populations. Ottawa, Ontario: Fisheries Research Board of Canada, Bulletin 191 (1975).

Ryan, P. M. Fyke net catches as indices of the abundance of brook trout, Salvelinus fontinalis, and Atlantic salmon, Salmo salar. Can. J. Fish. Aquat. Sci., 41: 377-380 (1984).

Sammons, S. M., C. G. Scalet, and R. M. Neumann. Seasonal and size-related changes in the diet of northern pike from a shallow prairie lake. J. Freshwater Ecol., 9: 321-329 (1994).

Sanders, R. E. Day versus night electrofishing catches from near-shore waters of the Ohio and Muskingum Rivers. Obio J. Sci., 92: 51-59 (1992).

Schorr, M. S. and L. E. Miranda. Catch of white crappie in trap nets in relation to soak time and fish abundance. Proc. Annu. Conf. Southeast Assoc. Fisb Wildl. Agencies, 43: 198 205 (1989).

Serns, S. L. Relationship of walleye fingerling density and electrofishing catch per effort in northern Wisconsin lakes. North Am. J. Fish. Manage., 2: 38-44 (1982).

Serns, S. L. Relationship between electrofishing catch per unit effort and density of walleye yearlings. North Am. J. Fish. Manage., 3: 451-452 (1983). 
Serns, S. L. Proportional stock density index - is it a useful tool for assessing fish populations in northern latitudes? Madison, WI: Department of Natural Resources, Research Report Number 132 (1985).

Van Den Avyle, M. J. Analysis of seasonal distribution patterns of young largemouth bass (Micropterus salmoides) by use of frequency-of-capture data. J. Fish. Res. Board Can., 33: 2427-2432 (1976).

Van Zee, B. E., D. W. Willis, and C. C. Stone. Comparison of diel sampling data for sauger collected by electrofishing. J. Freshwater Ecol., 11: 139-143 (1996).

Walburg, C. H. Fish sampling and estimation of relative abundance in Lewis and Clark Lake. Washington, D.C.: U.S. Fish and Wildlife Service, Technical Paper Number 18 (1969).

Waters, S. Fishing for trophy-sized fish. In: Iowa Fish and Fishing, pp. 295-300 (Harlan, J. R., E. B. Speaker, and J. Mayhew, Eds.). Iowa Department of Natural Resources (1987).

Wege, G. J. and R. O. Anderson. Relative weight (Wr): a new index of condition for largemouth bass. In: New Approaches to the Management of Small Impoundments, pp. 79-91 (Novinger, G. D. and J. G. Dillard, Eds.). Bethesda: North Central Division, American Fisheries Society, Special Publication Number 5 (1978).

Willis, D. W., B. R. Murphy, and C. S. Guy. Stock density indices: development, use, and limitations. Rev. Fish. Sci., 1: 203-222 (1993). 